\title{
Behaviour change guidance
}

\section{National Institute for Health and Clinical Excellence.}

Behaviour change at population, community and individual levels. NICE Public Health Guidance 6, 2007; London: National Institute for Health and Clinical Excellence

Scope and purpose This guidance was produced by the UK National Institute for Health and Clinical Excellence (NICE), in response to a request from the Department of Health, to produce public health guidance on the most appropriate generic and specific interventions to support attitude and behaviour change at population and community levels.

Methods This guidance was developed using the NICE public health programme process. Details of this process can be accessed at the NICE website (www.nice.org.uk/phmethods).

Review and updating With all NICE guidelines, a check for new evidence is made at 2 and 4 years after initial publication to decide whether all or part of the guidance should be updated. If important new evidence is published at other times, NICE may decide to update some recommendations at that time.

Recommendations This guidance outlines seven principles, the target audience and recommended actions. Three principles are related to planning of interventions and programmes, three to programme delivery and one to the evaluation of programmes (see Table 1). A number of gaps in the evidence were highlighted, as follows:

- Evidence about the cost-effectiveness of behaviour-change interventions is lacking.

- Interventions frequently fail to make a satisfactory link to health outcomes. Clear, consistent outcome measures need developing.

- Evaluations based on specific psychological models tend not to relate the outcome measures to the model. As a result, it is difficult to assess the appropriateness of using the model as a means of describing behaviour change.

- Few studies explicitly address the comparative effect that behaviour change interventions can have on health inequalities, particularly in relation to cultural differences.

- There is a need for more information on the links between knowledge, attitudes and behaviour. Conflation between them should be avoided.

- There is a lack of reliable data from which to extrapolate the long-term health outcomes of behaviour change interventions.

A series of recommendations relating to future research were also made.

\section{Commentary}

Dental health professionals are regularly involved in activities designed to help people to change their health-related knowledge, attitudes and behaviour. There have been a number of specific reviews related to the effectiveness of oral health education and promotion. ${ }^{1-5}$ This new guidance from NICE has been developed using standard procedures for public health programmes and provides a set of generic principles that can be used as the basis for planning, delivering and evaluating public health activities aimed at changing health-related behaviours. The guidance provides a useful update to the more specific oral health reviews and this reinforces many of the issues raised in those reviews.

The appendices in the full guideline provide helpful short summaries of the key behaviour theories but recognise that the reviews conducted for the guidelines were unable to capture all the material related to the very broad behaviour-change field.

This guidance reminds us of the difficulties not only in changing behaviour but understanding how this is achieved, and how we should plan and develop programmes to achieve behaviour change. This should be a starting point for all those engaged in these processes.

\section{Derek Richards}

Centre for Evidence-based Dentistry, Oxford, UK

1. Schou L, Locker D. Oral health: a review of the effectiveness of health education and health promotion. Amsterdam: Dutch Centre for Health Promotion and Health Education; 1994.

2. Kay L, Locker D. Is dental health education effective? A systematic review of current evidence. Community Dent Oral Epidemiol 1996; 24:231-235.

3. Sprod A, Anderson R, Treasure E. Effective oral health promotion. Literature Review. Cardiff: Health Promotion Wales; 1996.

4. Kay L, Locker D. A systematic review of the effectiveness of health promotion aimed at promoting oral health. London: Health Education Authority; 1997.

5. Watt RG, Marinho VC. Does oral health promotion improve oral hygiene and gingival health? Periodontol 2000 2005; 37:35-47.

Evidence-Based Dentistry (2007) 8, 98-100. doi:10.1038/sj.ebd.6400520 
Table 1. National Institute for Health and Clinical Excellence recommendations on behaviour change

\begin{tabular}{|c|c|c|}
\hline Principle & Target audience & Recommended action \\
\hline $\begin{array}{l}\text { Planning } \\
\text { interventions } \\
\text { and } \\
\text { programmes }\end{array}$ & $\begin{array}{l}\text { Policy makers, } \\
\text { commissioners, } \\
\text { service providers, } \\
\text { practitioners and } \\
\text { others whose work } \\
\text { impacts on, or who } \\
\text { wish to change, } \\
\text { people's health- } \\
\text { related behaviour }\end{array}$ & 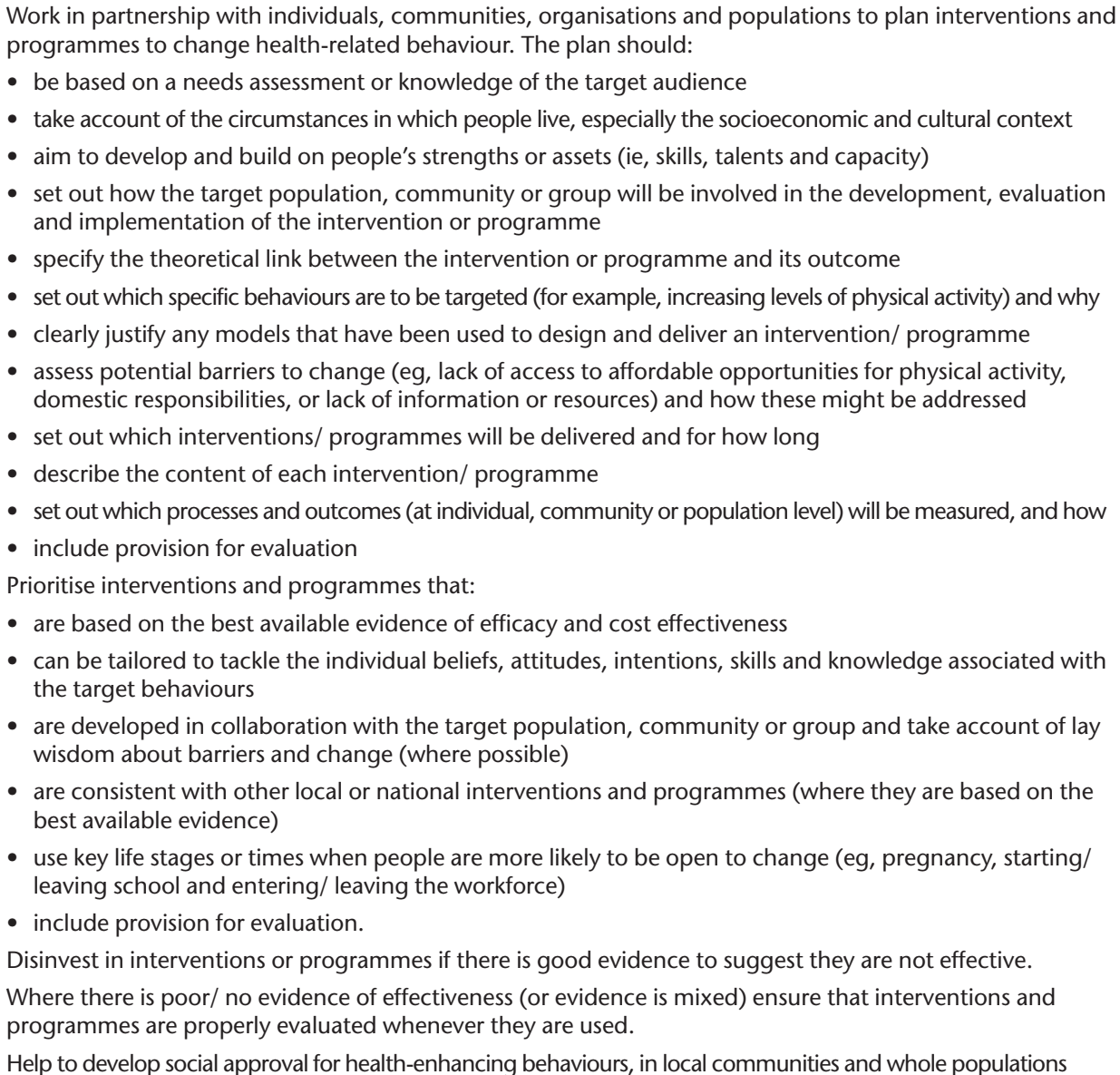 \\
\hline
\end{tabular}

\section{Assessing social} context
NHS and non-NHS policy makers and commissioners planning behaviourchange interventions or programmes for communities or populations, especially disadvantaged or excluded groups

Policy makers, commissioners, trainers, service providers, curriculum developers and practitioners
Identify and attempt to remove social, financial and environmental barriers that prevent people from making positive changes in their lives, eg, by tackling local poverty, employment or education issues.

Consider in detail the social and environmental context and how it could impact on the effectiveness of the intervention/ programme.

Support structural improvements to help people who find it difficult to change, or who are not motivated. These improvements could include changes to the physical environment or to service delivery, access and provision

Provide training and support for those involved in changing people's health-related behaviour so that they can develop the full range of competencies required. These competencies include the ability to:

- identify and assess evidence on behaviour change

- understand evidence on psychological, social, economic and cultural determinants of behaviour

- interpret relevant data on local or national needs and characteristics

- design, implement and evaluate interventions and programmes

- work in partnership with members of target population(s) and those with local knowledge.

Appropriate national organisations (eg, Faculty of Public Health, British Psychological Society, Chartered Institute of Environmental Health, Nursing and Midwifery Council) should consider developing standards for these competencies and skills. Standards should take into account different roles and responsibilities of practitioners working within and outside the NHS.

Ensure fair and equitable access to education and training, to enable practitioners and volunteers who help people to change their health-related behaviour to develop their skills and competencies.

Review current education and training practice in this area, and disinvest in approaches that lack supporting evidence 


\begin{tabular}{|c|c|c|}
\hline $\begin{array}{l}\text { Individual- } \\
\text { level } \\
\text { interventions } \\
\text { and } \\
\text { programmes }\end{array}$ & $\begin{array}{l}\text { Commissioners, } \\
\text { service providers and } \\
\text { practitioners working } \\
\text { with individuals }\end{array}$ & $\begin{array}{l}\text { Select interventions that motivate and support people to: } \\
\text { - understand short, medium and longer-term consequences of their health-related behaviours, for } \\
\text { themselves and others } \\
\text { - feel positive about benefits of health-enhancing behaviours and changing their behaviour } \\
\text { - plan their changes in terms of easy steps over time } \\
\text { - recognise how social contexts and relationships may affect their behaviour, and identify and plan for } \\
\text { - } \text { situations that might undermine the changes they are trying to make } \\
\text { - make a personal commitment to adopt health-enhancing behaviours by setting (and recording) goals to } \\
\text { - } \text { undertake clearly defined behaviours, in particular contexts, over a specified time }\end{array}$ \\
\hline $\begin{array}{l}\text { Community- } \\
\text { level } \\
\text { interventions } \\
\text { and } \\
\text { programmes }\end{array}$ & $\begin{array}{l}\text { NHS and non-NHS } \\
\text { policy makers and } \\
\text { commissioners } \\
\text { planning behaviour } \\
\text { change interventions } \\
\text { and programmes } \\
\text { for communities or } \\
\text { subgroups in the } \\
\text { population }\end{array}$ & $\begin{array}{l}\text { Invest in interventions and programmes that identify and build on strengths of individuals and communities } \\
\text { and relationships within communities. These include interventions and programmes to: } \\
\text { - } \text { promote and develop positive parental skills and enhance relationships between children and their carers } \\
\text { - improve self-efficacy } \\
\text { - develop and maintain supportive social networks and nurturing relationships (eg, extended kinship } \\
\text { networks and other ties) } \\
\text { - support organisations and institutions that offer opportunities for local people to take part in planning } \\
\text { - } \text { and delivery of services } \\
\text { - } \text { promote resilience and build skills, by promoting positive social networks and helping to develop relationships } \\
\text { - promote access to financial and material resources needed to facilitate behaviour change }\end{array}$ \\
\hline $\begin{array}{l}\text { Population- } \\
\text { level } \\
\text { interventions } \\
\text { and } \\
\text { programmes }\end{array}$ & $\begin{array}{l}\text { National } \\
\text { policy makers, } \\
\text { commissioners } \\
\text { and others whose } \\
\text { work impacts on } \\
\text { population-level } \\
\text { health-related } \\
\text { behaviour }\end{array}$ & $\begin{array}{l}\text { Deliver population-level policies, interventions and programmes tailored to change specific health-related } \\
\text { behaviours. These should be based on information gathered about context, needs and behaviours of target } \\
\text { population(s). They could include: } \\
\text { - fiscal and legislative interventions } \\
\text { - national and local advertising and mass media campaigns (eg, information campaigns, promotion of } \\
\text { positive role models and general promotion of health-enhancing behaviours) } \\
\text { - point-of-sale promotions and interventions (eg, working in partnership with private sector organisations } \\
\text { to offer information, price reductions or other promotions). } \\
\text { Ensure population-level interventions and programmes aiming to change behaviour are consistent with } \\
\text { those delivered to individuals and communities. } \\
\text { Ensure interventions and programmes are based on the best available evidence of effectiveness and } \\
\text { cost effectiveness. } \\
\text { Ensure risks, costs and benefits have been assessed for all target groups }\end{array}$ \\
\hline $\begin{array}{l}\text { Evaluating } \\
\text { effectiveness }\end{array}$ & $\begin{array}{l}\text { Researchers, } \\
\text { policy makers, } \\
\text { commissioners, } \\
\text { service providers and } \\
\text { practitioners whose } \\
\text { work impacts on, or } \\
\text { who wish to change, } \\
\text { people's health- } \\
\text { related behaviour }\end{array}$ & $\begin{array}{l}\text { Ensure funding applications and project plans for new interventions and programmes include specific } \\
\text { provision for evaluation and monitoring. } \\
\text { Ensure that, wherever possible, the following elements of behaviour-change interventions and programmes } \\
\text { are evaluated using appropriate process or outcome measures: } \\
\text { - effectiveness } \\
\text { - acceptability } \\
\text { - feasibility } \\
\text { - equity } \\
\text { - safety }\end{array}$ \\
\hline
\end{tabular}

